\section{The history of mining and metallurgy of metal ores in upper Silesia preserved in metallurgical waste dumps}

Iwona Jonczy, Michał Stawowiak

Silesian University of Technology, Poland

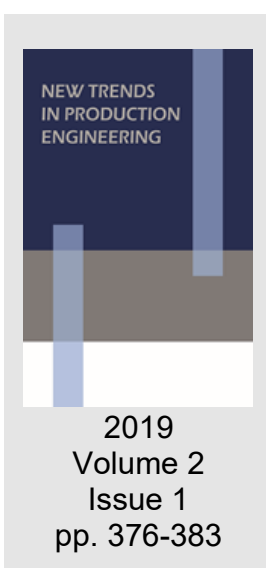

Date of submission to the Editor: 05/2019

Date of acceptance by the Editor: 08/2019

\title{
INTRODUCTION
}

Upper Silesia is one of the most developed regions in Poland. It is closely associated with the occurrence of rich mineral resources in this area, including hard coal and metal ores. It can be said that this is a natural consequence, because the development of previous societies has always been connected with the possibility of using resources. This is partially reflected in the scientific division of history of the development of human culture into the stone, bronze and iron age.

In the past, one of the most significant resources were zinc-lead ores, which were exploited in the area of present Upper Silesia - i.a. in: the Bytom Basin (1136), Repty (1247), Biskupice (1263), Miechowice, Piekary and Bobrowniki (1369). In the 16th century, Tarnowskie Góry and their nearest surroundings became an important centre producing silver and lead. However, a significant development of the zinc industry took place in the 19th century, when four significant zinc industry centres clearly emerged: Lipiny (owned by Bergwerksgesellschaft), Szopienice (owned by Giesche), Wełnowiec (owned by prince Hohenlohe) and Nowa Wieś (property of count Donnersmarck) (Boryczka and Blacha, 2002; Dworak, 1995; Pazdur, 1960; Popiołek, 1965).

In geological terms, zinc-lead ores are associated with ore-bearing dolomites, which, depending on the distribution range, include various stratigraphic layers of the Triassic. Primary ores are represented by zinc and lead sulphides - ZnS sphalerite and $\mathrm{PbS}$ galena. These formations on outcrops and in the impact zones undergo weathering processes quite easily; oxidized ores of this type are called calamine, and in their mineral composition there is i.a.: $\mathrm{ZnCO}_{3}$ smithsonite, $\quad \mathrm{Zn}_{2}\left[\mathrm{SiO}_{4}\right]$ willemite, $\mathrm{Zn}_{4}[\mathrm{OH}]_{2}\left[\mathrm{Si}_{2} \mathrm{O}_{7}\right] \cdot \mathrm{H}_{2} \mathrm{O}$ hemimorphite and $\mathrm{Zn}{ }_{5}[\mathrm{CO} 3]_{2}[\mathrm{OH}]_{3}$ hydrozincite. Calamine may also contain iron oxides and hydroxides, giving the ores a red colour. Depending on their presence, white calamine - poor in iron compounds and red calamine - containing significant amounts of iron oxides and hydroxides, can be distinguished (Chodyniecka and Zawiślak, 1983). Due to the ease of acquisition, calamine was the object of 
primary exploitation - the more so due to the fact that oftentimes after the exposure of the top, weathered layer, galena interburdens could be found. The exploitation of calamine was conducted in so-called "small mine fields". Usually, the main shaft for ore transporting was located in the middle of the field, with four small shafts on the sides. At the initial stage, small fields were mined to the water level, and then the exploitation moved to a new location. As late as in the second half of the 19th century the crisis associated with the depletion of calamine deposits caused the waste already collected on the dumping grounds to be reused and the methods of ore recasting were improved. What turned out to be a breakthrough solution was the use of sulphide ores - zinc blend, rich deposits of which were discovered in Upper Silesia in the 19th century. The exploitation of deposits located at greater depths forced the change of work organization; neighbouring mine fields were merged and the drainage system was developed - i.a. through the construction of drainage drifts (Dworak, 1995; Pazdur, 1960; Popiołek, 1965).

The course of the extraction of iron ore was similar. Initially, the subject of exploration was the turf ore, rich in limonite, constituting a mixture of iron oxides and hydroxides - mainly goethite and lepidocrocite with the same $\mathrm{FeOOH}$ formula, as well as clay minerals. Limonite often co-occurs with $\mathrm{Zn}$-Pb oxidized ore deposits with the aforementioned red calamine. Iron compounds discharged from the weathered massifs can accumulate in wetlands, precipitating porous concentrations of limonite on the plants. This is how the so-called marsh, turf or meadow ore is formed. Limonite can also be found on outcrops of iron ore located at greater depths. Similarly as in the case of calamine, the ease of acquiring limonite ores and their occurrence - practically on the surface of the earth - caused the fact that they were exploited in the first place (Chodyniecka and Zawiślak, 1983; Pazdur, 1960).

The shallow mining of metal ore was not conducive to the formation of too much mining waste, which is why there are no well-preserved ore mining historical sites in Upper Silesia. However, there are traces of metallurgical processing of metal ores, both zinc and lead as well as iron, carried out in Upper Silesia. In the past, the lack of communication tracts made it difficult or impossible to transport the extracted ore. Therefore, it was more profitable to build the entire infrastructure, with forges and residential buildings for the miners, at the ore mining sites. All smelters were located as close as possible to the ore mines, as well as coal mines in order to obtain fuel (Boryczka and Blacha, 2002; Pazdur, 1960; Popiołek, 1965).

Metallurgical production produced significant amounts of waste, mainly slags, which were not subject to any utilization or re-utilization, and were collected on dumping grounds directly in the vicinity of the metallurgical plants. Over the subsequent years, these wastes have also not been utilised. As a result, in some cities of Upper Silesia dumps of zinc wastes dated back to the 19th century can be found even today (Jonczy and Gawor, 2017).

One of the oldest Upper Silesian settlements engaged in mining and processing of $\mathrm{Zn}-\mathrm{Pb}$ ores was Ruda Śląska. The first mention of this subject dates back to 
in 1401. It is stated that in the area of the settlement, in the upper reaches of the Bytomka River, a lead-smelting forge was operating. After 1455, probably due to the depletion of ore resources, it was transformed into an ironworks. The current districts of Ruda Śląska, such as i.a. Wirek, were also thriving. As a settlement constituting the southern part of today's Nowa Wieś, Wirek (the German name of Wirek is Antonienhütte) came into existence at the beginning of the $17^{\text {th }}$ century, which is mentioned for the first time in sources from 1603. The flourishing of the settlement took place at the turn of the $18^{\text {th }}$ and $19^{\text {th }}$ centuries, which was related to the development of zinc metallurgy (Hugo and Miłość-Nadzieja zinc smelters) and iron metallurgy (Antonina ironworks) and the construction of the first coal mine. The history of industry in Wirek is confirmed by waste dumps preserved to this day; one of them is the dumping ground remaining after the activity of the Hugo smelter, which operated as a production plant in this area in the years 1812-1932 (Pazdur, 1960; Popiołek, 1965; Dworak and Ratka, 1985) (Fig. 1).

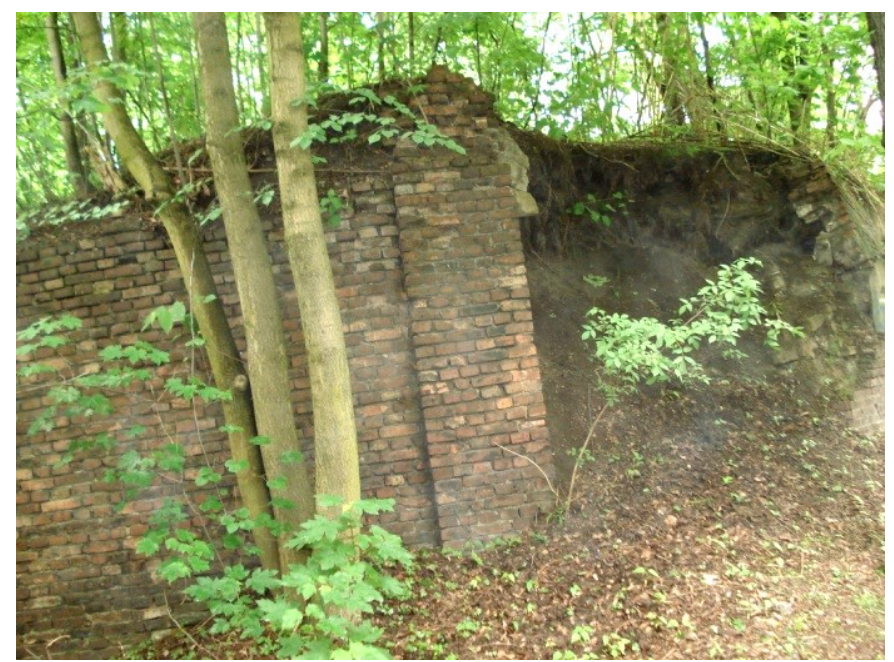

Fig. 1 A wall constituting a remnant of the Hugo zinc smelter buildings Source: Photo I. Jonczy

In this article, on the basis of the conducted research, the material collected on the waste dump in Ruda Śląska-Wirek was analysed in terms of the origin of the material the processing of which led to its creation.

\section{RESEARCH METHODOLOGY}

As a result of the conducted demolition works, including i.a. the removal of material from its central part, it was possible to take samples of slags located at the base of the dump. 10 samples of slags weighing approximately $2 \mathrm{~kg}$ each were collected for the tests. After being transported to the laboratory, the samples were described macroscopically and reduced using the quarting method. A part of each sample was ground in a mill with an agate liner to a grain size below $63 \mu \mathrm{m}$ and dried at $105^{\circ} \mathrm{C}$ for $2 \mathrm{~h}$. The second part was prepared for microscopic examination - 2-3 specimens were made for each sample. 
To establish the chemical composition of the analysed wastes, sample solutions were prepared; approximately $0.5 \mathrm{~g}$ of a sample was poured with a mixture of acids: $15 \mathrm{ml}$ of $\mathrm{HCl}$ and $5 \mathrm{ml}$ of $\mathrm{HNO}_{3}$. The samples were subject to mineralization using a UniClever II microwave mineraliser. The selected elements were identified using inductively coupled plasma - optical emission spectrometry (ICP-OES) using an ICPE 9800 emissive spectrometer manufactured by Shimadzu with a Teflon sample introduction system allowing for work with hydrofluoric acid. The content of $\mathrm{SiO}_{2}$ in slags was determined by means of an alkaline flux in the form of $\mathrm{Na}_{2} \mathrm{CO}_{3}$. The obtained results were converted to the Si concentration.

The tests using electron scanning microscopy were conducted in the Institute of Ceramics and Building Materials, Refractory Materials Division in Gliwice with the use of a microscope equipped with an electron gun in the form of Schottky emitter (accelerating voltage of 200 V-30 kV) and a Wide Field Optics optical system comprised of three electron lenses. Microscopic images were obtained using detectors: backscattered electrons detector BSE $(2.0 \mathrm{~nm}$ resolution at 30 $\mathrm{kV})$, secondary electrons (SE) detector $(1.2 \mathrm{~nm}$ ) working in high-vacuum mode, LVSTD low vacuum secondary electron detector $(1.5 \mathrm{~nm})$ and a CL cathodoluminescence detector (radiation range of $350-650 \mathrm{~nm}$ ).

\section{RESEARCH RESULTS}

Samples for testing were obtained at the foot of the heap slope from the layer with a characteristic red colour. This layer is clearly separated from the material lying above. The conducted drilling reached its substrate at a depth of about 20 $\mathrm{m}$ (Fig. 2). Slags forming this layer are the oldest waste material. They are characterised by a fine-grained structure and a not-so solid texture. Their characteristic red colour indicates that they were formed as waste material due to the processing of red calamine.

The composition of slags is dominated by variously preserved silica glass (Fig. 3, Tab. 1), apart from which small iron precipitates and oxide phases were represented, mainly by $\mathrm{Fe}_{2} \mathrm{O}_{3}$ hematite and $\mathrm{ZnFe}_{2} \mathrm{O}_{4}$ franklinite, as well as silicate phases, among which the $\mathrm{Mg}_{2}\left[\mathrm{SiO}_{4}\right]$ forsterite dominates.

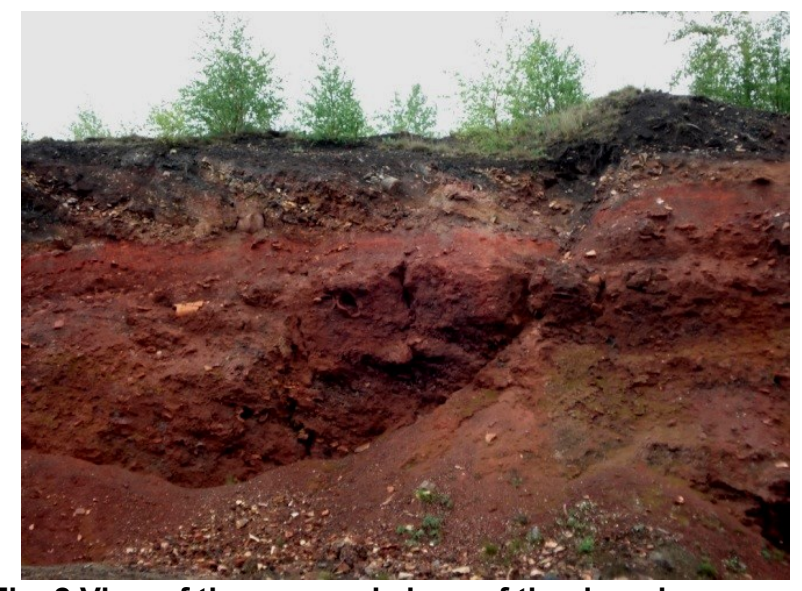




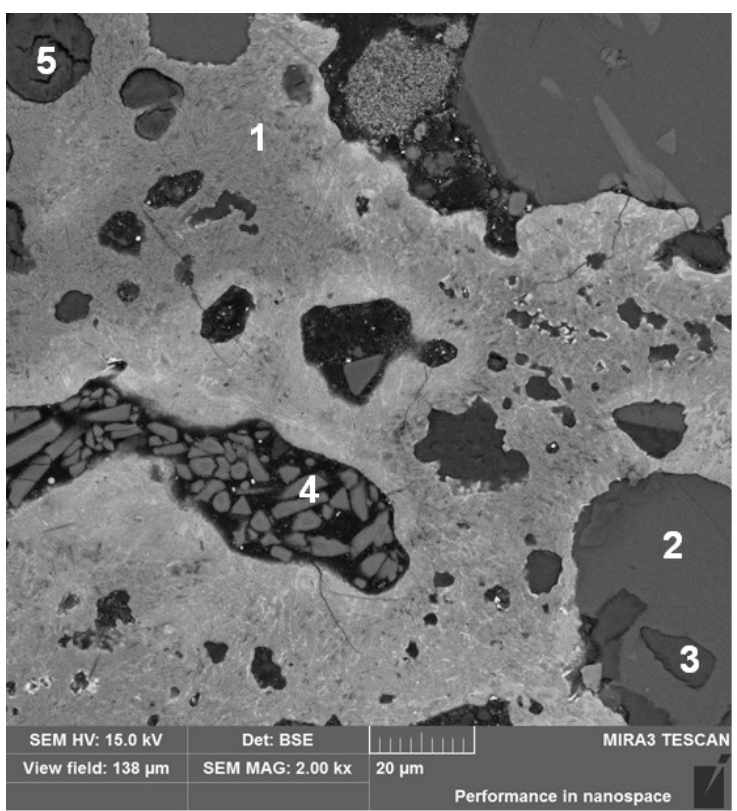

Fig. 3 Silica glass (point 1) and phase components (points 2-5) of the studied slag; an example of a BSE image

Table 1 Chemical composition of slag components; according to Fig. 3

Explanations:

\begin{tabular}{|l|c|c|c|c|c|}
\hline \multirow{2}{*}{ Element } & \multicolumn{5}{|c|}{ No. of analysis / Content [wt \%] } \\
\cline { 2 - 6 } & $\mathbf{1}$ & $\mathbf{2}$ & $\mathbf{3}$ & $\mathbf{4}$ & $\mathbf{5}$ \\
\hline $\mathrm{O}$ & 57.47 & 72.74 & 61.38 & 74.84 & 60.72 \\
\hline $\mathrm{Si}$ & 20.74 & - & 20.03 & - & 5.45 \\
\hline $\mathrm{Al}$ & 12.69 & - & 0.89 & - & 0.46 \\
\hline $\mathrm{Fe}$ & 0.28 & - & - & - & - \\
\hline $\mathrm{Mg}$ & 1.05 & - & 16.76 & 0.52 & 18.27 \\
\hline $\mathrm{Ca}$ & - & 13.09 & 0.15 & 24.14 & - \\
\hline $\mathrm{Na}$ & 0.60 & - & - & - & - \\
\hline $\mathrm{K}$ & 5.00 & - & 0.28 & - & - \\
\hline $\mathrm{S}$ & 1.10 & 14.17 & - & 0.51 & 15.11 \\
\hline $\mathrm{Pb}$ & 1.07 & - & - & - & - \\
\hline $\mathrm{Zn}$ & - & - & 0.51 & - & - \\
\hline $\mathrm{Total}$ & 100.00 & 100.00 & 100.00 & 100.00 & 100.00 \\
\hline
\end{tabular}

1 - silica glass; 2 -gypsum; 3 - silica phase (forsterite); 4 - calcite; 5 - magnesium sulphate

Particular attention should be paid to $\left(\mathrm{Zn}_{1,79} \mathrm{Mg}_{0,28} \mathrm{Fe}_{0.06}\right)\left[\mathrm{Si}_{0,93} \mathrm{O}_{4}\right]$ willemite, which occurs in this layer only. The presence of willemite was also established as a result of previous research on slags in another part of the dumping ground, where the red waste layer was only partially exposed on the surface (Jonczy, 2006; Jonczy, 2012).

As it has already been mentioned, willemite is one of the minerals characteristic of oxidised $\mathrm{Zn}-\mathrm{Pb}$ ores. Its presence in waste, in addition to a significant amount of iron oxides, may indicate the origin of the melted resource, which was red calamine, exploited and processed in the first years of the steel mill's operation. In the phase composition of slags, the presence of sulphides was no longer found. Undoubtedly, however, they were a component of waste, as indicated by the presence of quite significant amounts of sulphates, which recrystallised on the dump. Sulphides have been oxidised as a result of long-term storage of slags and the impact of weathering. Sulpahtes formed in the oxidation process crystallize in the heap, covering the slags with a white coating. Its main 
constituent is $\mathrm{CaSO}_{4} \cdot 2 \mathrm{H}_{2} \mathrm{O}$ gypsum (Fig. 4), apart from which magnesium sulphates are present in smaller amounts (Fig. 3, Tab. 1, point 5).

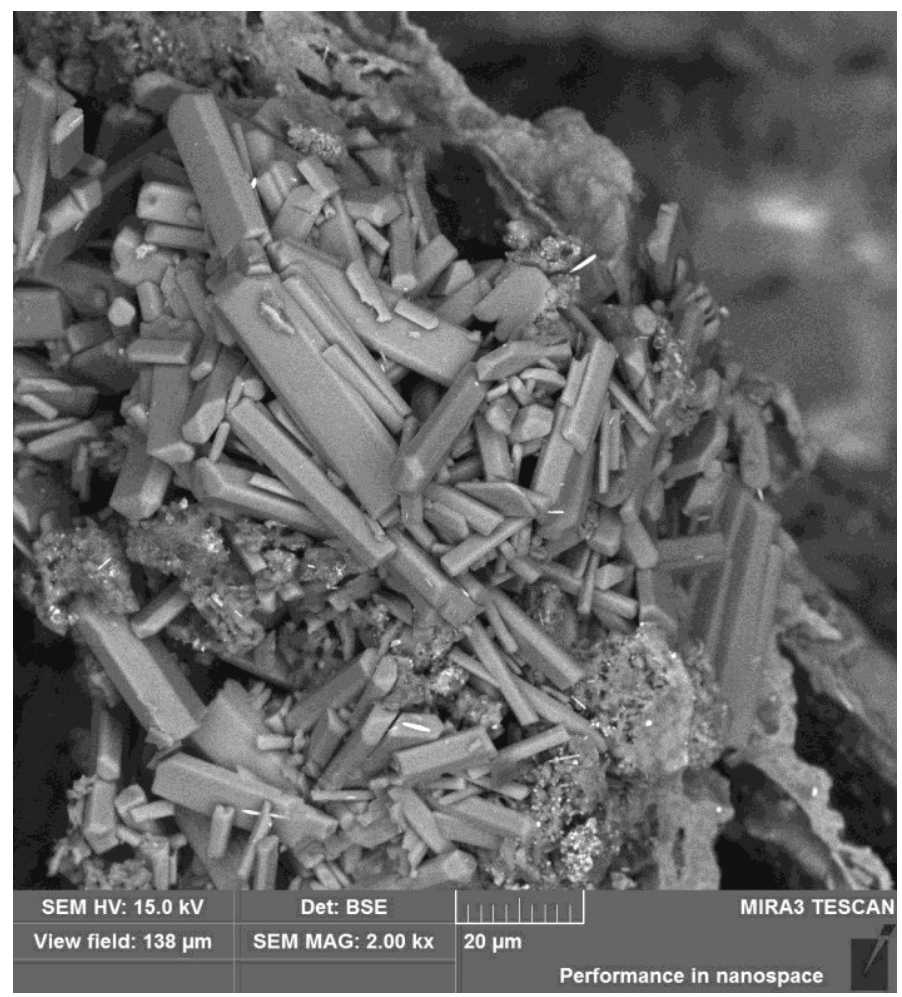

Fig. 4 Gypsum crystals; SEM image

When analysing the chemical composition of slags, it can be concluded that both calamine and sulphide ores were processed. Over more than a century of the mill's operation, the type of the resource used, along with the development of mining technology, could change. Initially, calamine ores deposited on the surface were used. The crisis in the second half of the $19^{\text {th }}$ century, associated with the depletion of calamine deposits, caused attempts to reuse wastes already deposited on the dumping grounds. At the same time, the methods of ore recasting were improved, which involved the reconstruction and modernisation of furnaces. What turned out to be a breakthrough solution was the use of sulphide ores - zinc blend, rich deposits of which were discovered in Upper Silesia. A significant concentration of zinc and lead as well as sulphur in the slags indicates that besides calamine, sulphide ores rich in $\mathrm{ZnS}$ zinc blend were also exploited and processed (Tab. 2).

It is also likely that during the approximately one hundred years of the production activity of the smelter, the type of processed ore was changing. Many historical sources contain information that such practices were quite popular in the previous centuries. The smelters were reclassified for processing another ores that were currently available. That is why old dumping grounds often accumulate material constituting a mixture of various types of metallurgical slags and mining waste. 
Table 2 Chemical composition of the studied slag

\begin{tabular}{|l|c|c|c|c|}
\hline \multicolumn{2}{|c|}{ Element } & \multicolumn{3}{c|}{ Content } \\
\cline { 3 - 5 } & min & max & average content \\
\hline $\mathrm{Al}$ & $\% \mathrm{wt}$ & 15.00 & 21.16 & 18.87 \\
\hline $\mathrm{Fe}$ & $\% \mathrm{wt}$ & 4.21 & 7.67 & 5.52 \\
\hline $\mathrm{Mn}$ & $\mathrm{ppm}$ & 0.35 & 11.86 & 8.04 \\
\hline $\mathrm{Mg}$ & $\% \mathrm{wt}$ & 0.89 & 3.42 & 6522.53 \\
\hline $\mathrm{Ca}$ & $\% \mathrm{wt}$ & 4.29 & 32.06 & 1.84 \\
\hline $\mathrm{Na}$ & $\mathrm{ppm}$ & 261.2 & 4807.6 & 12.65 \\
\hline $\mathrm{K}$ & $\mathrm{ppm}$ & 179.9 & 7889.2 & 1708.9 \\
\hline $\mathrm{P}$ & $\mathrm{ppm}$ & 247.2 & 4423.8 & 14239.7 \\
\hline $\mathrm{S}$ & $\% \mathrm{wt}$ & 0.44 & 4.63 & 1.72 \\
\hline $\mathrm{Ba}$ & $\mathrm{ppm}$ & 256.7 & 4757.9 & 1941.83 \\
\hline $\mathrm{Pb}$ & $\mathrm{ppm}$ & 19.8 & 3550.9 & 1055.37 \\
\hline $\mathrm{Zn}$ & $\mathrm{ppm}$ & 41.2 & 11953.8 & 5000.47 \\
\hline $\mathrm{Cd}$ & $\mathrm{ppm}$ & - & $310.2^{\star *}$ & - \\
\hline $\mathrm{As}$ & $\mathrm{ppm}$ & 57.8 & 816.5 & 270.62 \\
\hline $\mathrm{W}$ & $\mathrm{ppm}$ & $<36.3$ & 74.4 & 46.82 \\
\hline $\mathrm{La}$ & $\mathrm{ppm}$ & 5.9 & 51.0 & 28.83 \\
\hline $\mathrm{Dy}$ & $\mathrm{ppm}$ & 86.0 & 441.8 & 179.6 \\
\hline $\mathrm{Y}$ & $\mathrm{ppm}$ & $<1.5$ & 80.9 & 28.67 \\
\hline
\end{tabular}

* the average content was calculated for 10 samples

** the presence of cadmium was determined in a single sample

\section{CONCLUSION}

Phase and chemical composition tests of metallurgical slags conducted on the basis of a broad spectrum of mutually complementary research techniques can be a universal source of information. They are an indispensable element during works related to the development of economic opportunities for using slags. They also provide important data on the quality of the resource used, as well as its processing techniques. In the case when the metallurgical production took place in the $19^{\text {th }}$ and the beginning of the $20^{\text {th }}$ century and no historical documents have survived and there is no possibility of reconstructing them, the remaining metallurgical waste dumps are an important testimony of the past activity. It can be argued that the history of mining and, at the same time, the ore industry in Upper Silesia, is documented not only by the remaining buildings of industrial plants, but also metallurgical waste dumps, because in the past centuries these two branches of industry were inseparable.

\section{REFERENCES}

Boryczka, A. and Blacha, L. (2002). Hutnictwo cynku na Śląsku do końca XIX wieku. Rudy i Metale Nieżelazne, 47, pp. 369-374.

Chodyniecka, L. and Zawiślak, L. (1993). Mineralogia i petrografia kopalin metalicznych i chemicznych. Gliwice: Politechnika Śląska.

Dworak, J.S. (1995). Karol Godula. Opole-Ruda Śląska: Państwowy Instytut Naukowy, Instytut Śląski w Opolu, Związek Górnośląski, koło Nowy Bytom w Rudzie Śląskiej. 
Dworak, J.S. and Ratka, A. (1985). Ruda Śląska - przewodnik. Ruda Śląska: Towarzystwo Przyjaciół Miasta Rudy Śląskiej, Oddział Miejski Polskiego Towarzystwa Turystyczno-Krajoznawczego w Rudzie Śląskiej.

Jonczy, I. (2006). Charakterystyka mineralogiczno-chemiczna zwałowiska odpadów poprodukcyjnych huty cynku i ołowiu w Rudzie Śląskiej-Wirku oraz jego wpływ na środowisko. Gliwice: Wydawnictwo Politechniki Śląskiej.

Jonczy, I. (2012). Formy występowania wybranych metali w żużlach hutniczych na tle ich właściwości geochemicznych. Gospodarka Surowcami Mineralnymi - Mineral Resources Management, 28(1), pp. 63-75.

Jonczy, I. and Gawor, Ł. (2017). Coal mining and post-metallurgic dumping grounds and their connection of raw materials in the region of Ruda Sląska (Upper Silesia, Poland). Archives of Mining Sciences, 62(2), pp. 301-311.

Jonczy, I., Fornal, P. and Stanek, J. (2015). Mössbauer spectroscopy in the studies of iron phases of slags after zinc and lead production. Archives of Foundry Engineering, 15(3), pp. 21-24.

Pazdur, J. et al. (1960). Zarys dziejów górnictwa na ziemiach polskich. Katowice: Wydawnictwo Górniczo-Hutnicze.

Popiołek, K. (1965). Górnośląski przemysł górniczo-hutniczy w drugiej połowie XIX wieku. Katowice-Kraków: Śląski Instytut Naukowy w Katowicach.

Ratka, A. (1995). Ruda Śląska (1295-1995). Ruda Śląska: Urząd Miejski w Rudzie Śląskiej i Towarzystwo Przyjaciół Rudy Śląskiej.

\begin{abstract}
.
The history of mining and metallurgy in Upper Silesia dates back to the early Middle Ages. Initially, appearing on the surface, calamine, i.e. oxidized zinc-lead ores, and limonite - iron ore were used. The development of mining technology allowed for exploitation of ore deposits at greater depths. It contributed to the intensive development of industry at the turn of the 19th and 20th centuries. At that time, one of the most important industrial settlements was today's Ruda Śląska. In its area, apart from hard coal mines, there were several forges processing locally exploited zinc, lead and iron ore. The testimony of the former mining and metallurgy, among others, is the dump, which is a remnant of the Hugo zinc smelter (1812-1932). Mineralogical and chemical analyzes of waste material collected on the dumping ground provide a lot of interesting information about the processed raw material.
\end{abstract}

Keywords: metal ores, metallurgical waste, waste dump 